A Gospel for the Poor 
This page intentionally left blank 


\title{
A Gospel for the Poor
}

\author{
Global Social Christianity \\ and the Latin American Evangelical Left
}

David C. Kirkpatrick

\section{$\overline{\text { PENN }}$}

UNIVERSITY OF PENNSYLVANIA PRESS

PHILADELPHIA 
Copyright @ 2019 University of Pennsylvania Press

All rights reserved. Except for brief quotations used for purposes of review or scholarly citation, none of this book may be reproduced in any form by any means without written permission from the publisher.

\author{
Published by \\ University of Pennsylvania Press \\ Philadelphia, Pennsylvania 19104-4112 \\ www.upenn.edu/pennpress \\ Printed in the United States of America \\ on acid-free paper
}

13579108642

Library of Congress Cataloging-in-Publication Data

Names: Kirkpatrick, David C., author.

Title: A gospel for the poor : global social Christianity and the Latin

American evangelical left / David C. Kirkpatrick.

Description: 1st edition. | Philadelphia : University of Pennsylvania Press, [2019] | Includes bibliographical references and index.

Identifiers: LCCN 2018046938 | ISBN 9780812250947 (hardcover)

Subjects: LCSH: Evangelicalism-Latin America-History-20th century. |

Liberalism (Religion) - Protestant churches-History-20th century. |

Social gospel-Latin America-History-20th century. | Church and social problems-Protestant churches-History-20th century. | Christianity and politics-Latin America-History-20th century. | Latin America-Church history-20th century.

Classification: LCC BR1642.L29 K57 2019 | DDC 278/.082-dc23

LC record available at https://lccn.loc.gov/2018046938 
For Anna 
This page intentionally left blank 